\title{
El Derecho canónico, la visita episcopal y la Audiencia eclesiástica como medios de reforma de la Iglesia Católica en la temprana modernidad. El caso del obispado de Michoacán, 1640-1646*
}

Canon Law, the Episcopal Visit and the Ecclesiastical Audience
as a means of reform of the Catholic Church in early modernity.
The case of the Bishopric of Michoacán, $1640-1646$

Jorge E. TRASLOSHEROS

Instituto de Investigaciones Históricas

Universidad Nacional Autónoma de México

https://orcid.org/0000-0003-1859-7952

jtraslos@unam.mx

\begin{abstract}
We explore the process of reform carried out by Bishop Marcos Ramírez de Prado in the diocese of Michoacán, from 1640 to 1646 . Two aspects stand out. On the one hand, the emphasis on the dignity of sacred places, such as churches and hermitages; the execution of wills and the development of chaplaincies; the life of the clergy; and the customs of the faithful. On the other hand, the elaboration of diocesan Canon law, the episcopal visitation and the Ecclesiastical Court as means of reform, which gave it a markedly disciplinary character.
\end{abstract}

Keywords: Catholic reform; Canon Law; Episcopal visit; Ecclesiastical Court.
Resumen: En el presente texto exploraremos el proceso de reforma llevado a cabo por el obispo fray Marcos Ramírez de Prado en la diócesis de Michoacán, de 1640 a 1646 , por ser el momento inicial y decisivo. Destacan dos aspectos. Por un lado, el énfasis en el decoro de los lugares sagrados, como iglesias y ermitas; el cumplimiento de los testamentos y desarrollo de las capellanías; la vida de los clérigos y; las costumbres de los fieles. Por otro lado, que se usaron como medios de reforma la elaboración de Derecho canónico diocesano, la visita episcopal y la Audiencia eclesiástica, lo que le otorgó un carácter marcadamente disciplinario.

Palabras clave: Reforma católica; Derecho canónico; visita episcopal; Audiencia eclesiástica.

* Investigación realizada dentro del Proyecto del Ministerio de Ministerio de Economía y Competitividad Proyecto I+D: Justicia eclesiástica y conformación de la sociedad en la América Hispana colonial HAR2012-35197 
Mucho se ha reflexionado sobre la reforma de la Iglesia Católica en la llamada temprana modernidad, antes y después del Concilio de Trento, como también dentro de los territorios de la Monarquía de España y, en ella, de las Indias Occidentales $^{1}$. Para el caso de la Nueva España se ha robado la atención de los historiadores del virreinato el obispo don Juan de Palafox y Mendoza, por muchas y justas razones; pero en manera alguna fue el único. Por lo regular, la lógica política ha ocupado el centro de las preocupaciones ${ }^{2}$.

En el presente artículo queremos bajar a ras de suelo para observar cómo opera una reforma eclesiástica en la cotidianidad de la vida de un obispo de la Nueva España, en el segundo tercio del siglo XVII, cuando aquella sociedad había consolidado sus instituciones y alcanzado su estabilidad. Nuestra perspectiva no será la de los grandes procesos y conflictos políticos en momentos álgidos, sino de los pequeños y decisivos pasos que no generan mayor problema, pero que dejan huella profunda en la historia. Por decirlo así, entraremos al taller del orfebre para observar qué instrumentos escoge y cómo los maneja hasta moldear la materia y lograr el objeto buscado.

Así como descenderemos al taller del orfebre, escogeremos un artesano menos célebre, más humilde, pero no menos significativo. Procederemos de este modo porque estoy convencido de que, sólo en la medida en que estudiemos estos procesos a ras de suelo podremos comprender realmente sus medios, alcances e intenciones. Y no hay más camino que movernos al estudio de casos muy concretos como el que aquí proponemos.

Entre los años de 1640 y 1666 el obispado de Michoacán, tercero en importancia de la Provincia Eclesiástica de México, virreinato de la Nueva España, fue sometido a reforma por el obispo franciscano fray Marcos Ramírez de Prado. Según él mismo explicó, su intención era poner en orden distintos aspectos materiales y espirituales de la Iglesia para la salvación de las almas, en descargo de su

1 La bibliografía es vasta sin duda alguna. Ahora quiero referir cuatro textos. John W. O'MALLEY, Trento. ¿Qué pasó en el concilio?, Maliaño (Cantabria), 2015. John M. HEADLEY y John B. ToMARO (coords.), San Carlo Borromeo. Catholic Reform and Ecclesiastical Politics in the Second Half of the Sixteenth Century, Washington, London and Toronto, 1988. Stafford PoOLE, Pedro Moya de Contreras: reforma católica y poder real en Nueva España, Zamora, México, 2012. Leticia PÉREZ PUENTE, Los cimientos de la iglesia en la América española. Los seminarios conciliares, siglo XVI (La Real Universidad de México. Estudios y textos, 36), México, 2017.

2 En el caso palafoxiano la bibliografía también es abundante. Por ejemplo, para una comprensión política de su accionar en el contexto virreinal, Jonathan I. ISRAEL. Razas, clases sociales y vida política en el México Colonial. 1610-1670, México, 1980, p. 193-220. Una visión más amplia nos la entrega Cayetana ÁLVAREZ DE TOLEDO, Politics and Reform in Spain and Viceregal Mexico: The Life and Thought of Juan de Palafox, 1600-1659, New York, 2004. 
conciencia y de la conciencia del rey. Muchos fueron los recursos de los cuales se valió para alcanzar sus fines, pero destacan tres de manera muy especial: sus Ordenanzas de visita, la visita casi permanente al obispado y la Audiencia episcopal con su red de jueces comisionados y regionales. En el presente artículo nos centraremos en los años que van de 1640 a 1646, por ser la primera y decisiva etapa de la reforma de aquella vasta diócesis, la cual abarcaba desde las provincias de Tierra Caliente, Zacatula y Colima en el Océano Pacífico, hasta las misiones de Río Verde en San Luis Potosí, pasando por la meseta tarasca y el bajío, entonces conocido como provincia de chichimecas ${ }^{3}$.

\section{UN OBISPO REFORMADOR}

Fray Marcos Ramírez de Prado arribó a la ciudad de Valladolid, cabeza del obispado de Michoacán, el 19 de noviembre de 1640, procedente de la diócesis de Chiapas. Veintiséis años después salió para ocupar la sede del Arzobispado de México, donde falleció en 1668. Si alguna palabra define su historia dentro de la Nueva España es la de reformador ${ }^{4}$.

Antes de entrar en la sede de la diócesis de Michoacán ya había iniciado la visita general al obispado. Tiempo después le informaría al rey como:

luego que entré en aqueste obispado de Michoacán, comencé a visitarle por venir informado, como experimenté, que con ocasión de la muerte de mi antecesor, de gloriosa memoria, en su vacante la malicia humana tenía algo estragadas

3 Es bien conocido que el obispado de Michoacán fue erigido en 1534 por el Papa Paulo III mediante la Bula Illius fulciti praesidio. También lo es que su primero obispo fue el célebre don Vasco de Quiroga, quien tomó posesión el 6 de agosto de 1638 y que, durante su larga gestión se caracterizó por su pasión por el Derecho dejando su impronta hasta nuestros días. En el siglo XVII el canónigo y posteriormente obispo de Puerto Rico don Franco Arnaldo Yssasy, a su vez uno de los hombres más cercanos a Ramírez de Prado, caracterizó a don Vasco como un celoso pastor defensor de los derechos de la Iglesia y de la feligresía muy a tono con la acción reformadora de fray Marcos. La influencia de Quiroga en Ramírez de Prado es algo que aún está por determinarse. Y si bien es cierto que en las actuaciones y escritos de nuestro obispo no hay referencias que pudieran presumir una inspiración directa, también lo es que siempre apoyó al Cabildo de la Catedral vallisoletana en la defensa del patronato que ejercía sobre el Hospital Pueblo de Santa Fe de los Altos de México, prístina herencia de don Vasco de Quiroga, contra las pretensiones del arzobispado de México. Cfr. Franco Arnaldo YSASSY, Demarcación y descripción de el obispado de Michoacán y fundación de su iglesia catedral (1649), en Biblioteca Americana, vol. 1, n. ${ }^{\circ} 1$ (septiembre, 1982).

4 Para un estudio más amplio sobre este obispo: Jorge E. TRASLOSHEROS, La reforma de la Iglesia del Antiguo Michoacán, Morelia, 1995. Ramírez de Prado no es tan famoso como don Juan de Palafox y Mendoza. Sin embargo, no es menos importante para efectos del desarrollo de la Iglesia en Nueva España. 
las ordenanzas y mandatos que con el desvelo de su buen proceder y gobierno tenía promulgadas por todo el obispado, y aun las costumbres de los súbditos en todos los estados estimuló que apresurara mi viaje hasta llegar a la ciudad de Valladolid 5 .

Con estos problemas en mente, emprendió intensa visita por todos los rincones de su nueva diócesis. En la primera etapa recorrió el norte del obispado por la llamada provincia de Chichimecas, entre cuyos lugares destacan el Real de minas de Guanajuato, San Francisco del Rincón, San Luis Potosí, San Miguel, Celaya y Salamanca, para regresar a Valladolid en 29 de enero de 1642. En una segunda etapa, visitó toda la sierra «que llaman de Michoacán» y 30 leguas en su contorno, para regresar a la sede a finales de agosto de 1642. Hay alguna evidencia de su paso por Santiago Undameo, Tacámbaro y Zamora. No pudo visitar en persona Zacatula, Colima y Tierra Caliente; pero mandó a dos jueces visitadores comisionados: al Pbro. Pedro Gutiérrez Rangel, quien recorrió Colima, Zacatula y parte de Tierra Caliente en 1641; y al Pbro. Jacinto López de Mesa, quien visitó la mayor parte de Tierra Caliente en ese mismo año.

Sin distinguir entre doctrinas o beneficios adscritos a regulares o seculares, fray Marcos y sus jueces visitaron iglesias, capillas, ermitas, sagrarios, crismeras de santos óleos, libros de partida (bautizos, casamientos y entierros), construcciones, hospitales, cofradías, testamentos, capellanías y obras pías y la «vida y costumbres» de clérigos y no clérigos, como principales aspectos. Centraron su atención en cuatro rubros: el «orden y decoro» de los espacios sagrados, es decir, los lugares destinados al culto divino; la «vida y costumbres» de la feligresía; que la vida del clero sirviera de «ejemplo y edificación» de los fieles y; el cumplimiento de los testamentos y las obras pías. Todo, en cumplimiento de sus obligaciones como «pastor y prelado».

Entre los muchos problemas que encontró, uno de los más serios era el notable vacío jurídico, es decir, no había una normatividad clara que sirviera para ordenar la vida de la Iglesia; en sus propias palabras para «contenerla en la disciplina». Hacía falta un cuerpo de disposiciones canónicas de validez general dentro del obispado, a las cuales todos y cada uno de los clérigos, religiosos y laicos se sujetaran. Pero también era urgente tener una institución capaz de hacerlas

5 MORELIA, ARCHIVO HISTÓRICO MANUEL CASTAÑEDA RAMÍREZ, CASA DE MORELOS. En adelante AHMCR. Borrador de carta al rey sin fecha; por su contenido muy probablemente sea del año 1643, Negocios diversos, leg. 9 (1642-43). 
cumplir. En esta lógica dictó sus Ordenanzas Generales de Visita y realizó una eficaz reforma judicial ${ }^{6}$.

Las Ordenanzas buscaban, en palabras de Ramírez de Prado: «en servicio de Dios Nuestro Señor [...] entablar algunas cosas, reformar abusos de otras y ordenar en todo lo que a nuestro corto entender más sea de su santa voluntad, descargo de la conciencia de Su Majestad y nuestra $>^{7}$. Sus mandatos obligaban directamente a todos los beneficiados, curas y vicarios, así como a todos los clérigos, en servicio de la necesidad de los feligreses, muy en particular de los indios a quienes Dios y el rey le habían confiado ${ }^{8}$. Se dividen en seis grandes capítulos en los cuales se trata, como materias principales: «De la administración de los santos sacramentos», confesión, eucaristía, extremaunción, matrimonio y confirmación; «De la doctrina», su enseñanza, organización y materias, dirigido de manera especial a los indios; «De las iglesias», el uso y decencia de los templos y ornamentos; «De las personas» lo relacionado con la vida y costumbres de los clérigos, su aspecto, vestido, mujeres, juegos, relación con la potestad secular; «De las obvenciones», la moderación en su cobro, misas, entierros; «De los naturales», su trato. Entre sus líneas sobresale el combate sin cuartel al pecado público y escandaloso como el principal enemigo a vencer, en mor del orden y disciplina de la Iglesia y de la sociedad.

Si fray Marcos quería que sus Ordenanzas fueran eficaces para la reforma de su Iglesia, era necesario que tuvieran toda la fuerza jurídica que pudiesen obtener. La canónica se las daba Ramírez de Prado por el ejercicio pleno de su potestad

6 El texto que aquí utilizaremos de las Ordenanzas Generales de Visita se encuentra en la reimpresión hecha a expensas de don Francisco CASILlAS y CABRERA, notario público y oficial mayor de la secretaría de cámara y gobierno del Señor Dean y Cabildo sede vacante de la Iglesia michoacana, en México, por don Felipe de Zúñiga y Ontiveros, 1776. Lleva por título, Colección de las ordenanzas que para el gobierno de el obispado de Michoacán bicieron y promulgaron con real aprobación sus ilustrísimos señores prelados, de buena memoria, D. fr. Marcos Ramírez de Prado y D. fuan de Ortega y Montañez. La versión manuscrita con aprobación real se puede localizar en el AHMCR, Negocios diversos, leg. 9 (1642-1643). Tenemos noticia, por la sesión del Cabildo Catedral de Valladolid del 28 de marzo de 1645, que fue presentada a los capitulares por el obispo Ramírez de Prado junto con su permiso del virrey para su impresión en México. Según el Manual del librero bispanoamericano de don Antonio PALAU y DULCET, su primera edición es de 1657. Según don José TORIBIO MEDINA, en su obra La imprenta en México (1534-1821), México, 1989, vol. 2, ficha 844, la primera edición de 1657 se agotó rápidamente, por lo que ese mismo año Juan de Aranda solicitó su reimpresión, aprobada el 4 de septiembre de 1657 y de la cual salió la reimpresión de 1776, según la licencia concedida por la sede vacante para la publicación referida en la misma edición.

7 Colección de las ordenanzas que para el gobierno del obispado de Michoacán..., p. 2.

8 Ibidem. 
de orden y jurisdicción ${ }^{9}$, además de los cuatro pilares en que se sustentaban que eran, según lo explicó nuestro obispo en distintos escritos: el precedente canónico de Michoacán expresado por las disposiciones disciplinarias de sus antecesores $^{10}$, el Tercer Concilio Provincial Mexicano, el Concilio de Trento ${ }^{11}$ y diversas reales cédulas ${ }^{12}$. Sobre esta base mandaba se cumpliesen con «la fuerza, orden a su vigor y conforme a derecho deben y pueden tener las que para reformación de costumbres se hacen en tiempo de visita general» ${ }^{13}$. Y al respecto el Concilio de Trento era muy generoso. En cuanto a la visita:

El objetivo principal [...] ha de ser introducir la doctrina sana y católica, y expelir las herejías; promover las buenas costumbres y corregir las malas; inflamar al pueblo con exhortaciones y consejos a la religión, paz e inocencia, y arreglar todas las demás cosas de utilidad de los fieles ${ }^{14}$.

En razón de estos objetivos dotaba a los obispos de plenos poderes, sin los cuales ninguna corrección podría llegar a ser efectiva. Por ello disponía:

Para que los obispos puedan más oportunamente contener en su deber y subordinación al pueblo que gobiernan, tengan derecho y potestad [...] de ordenar, moderar, castigar y ejecutar, según los estatutos canónicos, cuanto les pereciera necesario según su prudencia, en orden a la enmienda de sus súbditos y a la utilidad de su diócesis, en todas las cosas pertenecientes a la visita, y a la corrección de las costumbres. Ni en las materias en que se trata de la visita, o de dicha corrección, impida o suspenda de modo alguno la ejecución de todo cuanto mandaren, decretaren, o juzgaren los obispos, exención ninguna, inhibición, apelación o querella, aunque se interponga para la ante sede apostólica. ${ }^{15}$

9 La potestad de los obispos se dividía en orden y jurisdicción. En la primera se incluían todos los actos que dependían del carácter sacramental del orden episcopal. En la segunda, se enmarcaban los actos que no requirieran de la condición sacramental. Pedro MURILLO VELARDE, Curso de Derecho canónico e indiano, Zamora, México, 2004, Libro Primero de las Decretales, título XXXI «Del oficio del juez ordinario», n. ${ }^{\text {os }} 331$ y 332. Juan de SOLÓRZANO Y PEREYRA, Política Indiana, Madrid, 1972, Libro cuarto. Domingo CaVALLARIO, Instituciones del Derecho canónico, imprenta de Don José María Repullé, Madrid, 1838, tomo I, pp. 1, 2, 109, 232, cuya primera edición data de 1793.

10 Colección de las ordenanzas que para el gobierno del obispado de Michoacán..., p. 4.

11 Gil GOnZález Dávila, Teatro eclesiástico de la primitiva Iglesia de las Indias Occidentales, Madrid, por Diego Díaz de la Carrera, 1649, p. 107 y ss. El mismo autor señala que la información sobre nuestro obispo proviene de una carta que le hizo llegar desde Michoacán, con fecha del 27 de abril de 1646.

12 Borrador de carta al rey de 1643, Negocios diversos, leg. 9 (1642-43).

13 Colección de las ordenanzas que para el gobierno del obispado de Michoacán..., p. 3.

14 Sacrosanto y ecuménico Concilio de Trento, París, México, 1885, Sesión XXIV, Decreto de reforma, cap. III.

15 Ibid., Sesión XXI, Decreto de reforma, cap, X. 
A su vez, la Iglesia de México en el Tercer Concilio Provincial, celebrado en 1585 , hacía suyas las disposiciones del tridentino acorde a la realidades indianas ${ }^{16}$; en tanto que su Majestad, en calidad de patrón de las Indias Occidentales, retomaba lo dispuesto por la tradición conciliar provincial y universal ${ }^{17}$.

Ahora bien, en un orden eclesiástico sujeto a régimen de Patronato Real, como el indiano, no era suficiente el peso de la tradición canónica, también hacía falta contar con la autorización del rey. Por lo mismo, terminadas el 6 de enero de 1642, se envían a España donde Felipe IV, habiéndoles visto en el Consejo de Indias, las aprobó y confirmó en Zaragoza a 18 de noviembre de 1643, adquiriendo con ello plena vigencia en el obispado de Michoacán como leyes propias del reino $^{18}$. En suma, fray Marcos Ramírez de Prado había dotado a su Iglesia de un poderoso instrumento de Derecho canónico diocesano emanado de una vasta y muy completa visita general.

Sin embargo, para garantizar que las Ordenanzas no fueran otra más de las víctimas del páramo de la desidia, además de un claro compromiso pastoral de la clerecía y buen recibimiento de la feligresía, era necesario apoyarlas por una institución capaz de hacerlas cumplir. Esa institución sería la Audiencia episcopal, también conocida como provisorato o tribunal eclesiástico ordinario ${ }^{19}$. El problema era que la Audiencia no estaba en mejor situación que el conjunto del obispado. Entre sus muchas dificultades se encontraba la falta de apoyo del Cabildo Catedral al provisor, la duplicidad de funciones y la dispersión de los juzgados regionales, por decir lo más importante.

Obvio es decir que, con la presencia de este decidido pastor el tribunal se reforzaba; pero no era suficiente con su sola voluntad. Con la clara intención

16 Tercer Concilio Provincial Mexicano, México, 1859, libro III, título primero y; libro V, título primero, como principales.

17 Recopilación de las leyes de los reinos de las Indias, México,1987, libro 1, título 7, ley 13.

18 Según las disposiciones de Felipe II de 1560 y 1590, referidas en la Recopilación..., libro 1, título 7, ley 6, solamente los concilios provinciales requerían aprobación del rey. Los sínodos diocesanos tan sólo del virrey y de Real Audiencia del distrito. Pero las Ordenanzas no eran ni lo uno ni lo otro. En otras palabras, fray Marcos no necesitaba de la aprobación real para que tuvieran plena vigencia dentro del obispado de Michoacán. Sin embargo la buscó, lo que nos da una idea del grado de importancia que les concedía para llevar a cabo su reforma.

19 La naturaleza y alcances de la Audiencia episcopal apenas lo estamos comprendiendo, más allá de las grandes caracterizaciones presentes en el Derecho canónico de la época. De manera personal he dedicado tiempo y trabajo a su estudio. Cfr. Jorge Traslosheros, Iglesia, justicia y sociedad en la Nueva España. La Audiencia del Arzobispado de México, 1528-1668, Porrúa, Universidad Iberoamericana Santa Fe, México, 2004. ID., Historia judicial eclesiástica de la Nueva España. Materia, método y razones, México, 2014. 
de fortalecer la figura del provisor y centralizar en la Audiencia el ejercicio de la justicia sobre cualquier instancia regional, fray Marcos reduce el número de juzgados eclesiásticos «quitando a los más de los beneficios la autoridad de jueces eclesiásticos» ${ }^{20}$. Así, como juzgados regionales, es decir, sedes de un vicario in capite y juez eclesiástico quedan San Luis Potosí, Celaya y Colima, dotados solamente con la facultad de seguir las causas hasta ponerlas en estado de sentencia, con la obligación de remitirlas a Valladolid para que el provisor o el obispo dispusieran lo que consideraran conveniente.

La acción del provisor y los jueces regionales se complementaría, por un lado, con jueces especiales para causas particulares a quienes se les darían facultades variables según el caso; pero sobre todo con jueces comisionados quienes por lo regular se encargarían de levantar las informaciones en el sitio de los sucesos, si bien algunos de éstos adquirieron calidad casi permanente como el de Tlazazalca. En todo caso, insistimos, las sentencias se reservaron al obispo y su provisor. Por último, a los beneficiados únicamente se les dejó la facultad de levantar informaciones matrimoniales, pero con la obligación de remitirlas cerradas y selladas ante el provisor o el obispo «para que si conviniere demos licencia para que se casen», aplicable sólo para españoles, mestizos, negros y mulatos ${ }^{21}$.

En su conjunto, acorde a los registros de archivo, las acciones de la Audiencia episcopal se orientaron principalmente a la defensa de la jurisdicción del obispo y la Iglesia; la defensa de los espacios sagrados; la persecución de los pecadores públicos y escandalosos fueran religiosos, clérigos o seglares; la atención de asuntos relativos a testamentos, capellanías y obras pías y; los problemas matrimoniales; apoyar el buen cobro del diezmo dispensando censuras y excomuniones contra los deudores morosos, e incluso procesando a algún desobediente en apoyo de y en coordinación con los jueces hacedores a través del mayordomo de la Catedral.

\section{LA VISITA EPISCOPAL Y LA AUDIENCIA ECLESIÁSTICA EN ACCIÓN COORDINADA}

Como podemos observar, la visita episcopal y la Audiencia eclesiástica son dos instancias de justicia bien diferenciadas en sus métodos y en sus fines. Mientras una se aboca a la supervisión y la prevención; la otra se ocupa princi-

20 Colección de las ordenanzas que para el gobierno del obispado de Michoacán..., p. 10.

21 Ibidem. 
palmente de la jurisdicción contenciosa. Mientras una es itinerante y la ejecuta el obispo de manera personal con apoyo de algunos jueces visitadores nombrados a discreción; la otra está encabezada por un provisor oficial quien ejerce jurisdicción ordinaria, la cual se expande a través de una red de jueces delegados, unos comisionados para asuntos específicos y otros regionales estratégicamente ubicados a lo largo de la diócesis ${ }^{22}$. Ambas, poderosas instituciones de reforma manejadas de manera coordinada y complementaria por fray Marcos Ramírez de Prado, con especial atención en cuatro asuntos: el espacio de lo sagrado; los testamentos y obras pías; la conducta de los clérigos y; la conducta de los fieles ${ }^{23}$. Obvio es decir, las Ordenanzas servirían como brújula para orientar las acciones.

\section{II.1. El espacio de lo sagrado}

Iglesias, capillas y ermitas, sin importar ubicación o importancia, debían ser lugares decentes, decorosos, reservados, limpios, honestos y edificantes, alejados de toda posibilidad de escándalo puesto que estaban destinados, como lugares santos, al culto divino. Dada su trascendencia ocuparon un lugar especial en las acciones del obispo de Michoacán.

En principio, ningún templo podía funcionar si no contaba con la licencia otorgada por el obispo, de manera especial las capillas de los particulares, y ganar estas licencias en tiempos de Ramírez de Prado no era tarea fácil. Primero, se tenía que presentar solicitud ante el obispo o su provisor; luego, había que esperar la supervisión del visitador comisionado al efecto y, si su dictamen era favorable por ser el lugar «decente y seguro de toda profanidad», esperar la licencia. Una vez conseguida, luchar por conservarla, pues cualquier inesperada vista o bien denuncia del beneficiado o de algún particular podía ser motivo de su cancelación.

La licencia dependía de que la capilla juntase los requisitos señalados por el concilio de Trento, breves apostólicos y Ordenanzas del obispo Ramírez de Pra-

22 Aclaremos que el obispo nunca dejaba de ser el juez supremo dentro de su diócesis, por lo que siempre podía atraer las causas que considerara pertinentes, sin dar mayor explicación.

23 Lo hecho por Ramírez de Prado no debe considerarse normativo para otros obispos. Nunca estará de más insistir en que, cada prelado tenía la libertad de echar mano de estos recursos acorde a sus objetivos pastorales. Sí podemos decir que Ramírez de Prado fue un prelado con vocación especialmente disciplinaria. 
do $^{24}$. Además, el lugar debía contar con un mínimo de objetos necesarios para el culto tales como crismeras de plata, cálices, altar, crucifijo, etc., esto es «que los ornamentos y demás adornos de plata, colgaduras, ropa y otras cosas del servicio de las iglesias se traten con mucha decencia, limpieza, devoción y fidelidad» ${ }^{25}$. Todo, condicionado a un conjunto de prácticas y prohibiciones que garantizaran su uso exclusivo para la oración como tener cerradura de hierro, no permitir que persona alguna de cualquier calidad o condición durmiera en ellas y que ningún clérigo sin licencia pudiese decir misa en ellas. Tampoco debían perjudicar los derechos parroquiales, así como estar plenamente justificada la necesidad de la capilla como auxilio a los fieles y al párroco del lugar.

Acorde a estos principios, el primero de julio de 1644, Ramírez de Prado mandaba a todos los curas, vicarios y ministros de doctrina regulares y seculares de los partidos de Salamanca, Irapuato, Guanajuato, Silao, León y pueblo de San Francisco del Rincón que cerrasen e impidiesen la celebración del culto en las capillas de esos lugares. El problema era que sus dueños habían permitido decir misa a clérigos vagos de otros obispados quienes deambulaban sin el permiso de sus obispos, entre ellos algunos excomulgados, suspensos o irregulares. Dada la gravedad del asunto se declaraban las capillas «por lugares [in]capaces e indecentes para poder celebrar en ellas», so pena de excomunión mayor, dos años de suspensión de oficios y beneficios, más 50 pesos de oro de multa a los dueños y a cada fiel que asistiese a esas misas ${ }^{26}$.

La medicina se repitió poco después en San Luis Potosí, sólo que el obispo se encontró con la resistencia de la república y diputados del pueblo. En carta dirigida al prelado, fechada en enero de 1645 , no sólo se quejaban amargamente contra la medida, también amenazaban al obispo con acudir a los tribunales superiores del rey por el gran daño que provocaba a las almas de los fieles, en especial a los indios y mujeres de lugares apartados. Pedían al obispo que:

imitando a Dios nuestro Señor, cuyo lugar representa, pues en los tiempos de mayor severidad bastó un justo para perdonar una ciudad entera, ahora por muchos se perdone lo que uno ha desmerecido, mandando revocar el despacho prohibitivo y que corra el uso y costumbre de las capillas ${ }^{27}$.

24 AHMCR. Licencia otorgada por el visitador de capillas de San Luis Potosí, Juan Herrera Sandoval, Negocios diversos, leg. 11 (1645).

25 Colección de las ordenanzas que para el gobierno del obispado de Michoacán..., p. 23.

26 AHMCR. Mandamiento del primero de julio de 1644, desde Pátzcuaro, en visita. Negocios diversos, leg. 10 (1644).

27 AHMCR. Negocios diversos, leg. 20 (1645). 
El 16 de febrero de 1645, desde la ciudad de Valladolid, el obispo respondía a la república y diputados de San Luis Potosí en el tenor siguiente:

Qué juez que sabe serlo se escondió jamás de los amagos para tribunales superiores. Mis Ordenanzas Generales de Visita, fiscaliadas y vistas por Su Majestad en su Real Consejo de las Indias, y por su piedad y grandeza confirmadas y mandadas guardar y cumplir por su real cédula en que volvieron insertas a mi mano, afianzan vastamente la proposición y aseguran los expedientes de mi gobierno $^{28}$.

Para reforzar sus indicaciones daba nueva comisión para la supervisión de las capillas a don Juan de Herrera Sandoval, vicario in cápite y juez eclesiástico de san Luis Potosí:

a cuya buena discreción, así como a la de mis deseos, deberá el de cada uno de los interesados el consuelo de lo que solicita y quedará advertido de lo que ha de procurar se excuse, que estará tan bien al gobierno doméstico de todos, como el general del obispado. En todo lo demás que se ofrezca a la muy noble y leal república de San Luis Potosí me tendrá con todo gusto ${ }^{29}$.

La supervisión se extendió a cualquier templo dentro del obispado y también fue aplicada en la iglesia parroquial de Pátzcuaro. Así, el 14 de mayo de $1644^{30}$, de visita en esa ciudad, hacía patente por mandamiento público cómo en la iglesia parroquial había personas que tenían entierros, sepulturas, altares con retablos y no los ofrendaban como era debido. Por lo mismo, y para saber con qué títulos y obligaciones las tenían, les mandaba so pena de excomunión mayor que, en plazo de seis días de leído el mandamiento en la iglesia, se presentasen ante el obispo. Si no acreditaban todo como era debido, pasarían a formar parte de la fábrica de la iglesia «para que se disponga como sea conveniente».

\section{II.2. De los testamentos y las capellanías}

Parte importante de las visitas de fray Marcos Ramírez de Prado fue la supervisión del cumplimiento de los testamentos, responsabilidad particular de los albaceas nombrados por el testador. En cada lugar, sea por visita general o par-

\footnotetext{
28 Ibidem.

29 Ibidem.

30 AHMCR. Negocios diversos, leg. 10 (1644).
} 
ticular, el visitador solicitaba al escribano público la relación de los testamentos otorgados en cierto período de tiempo, por lo regular desde la última visita.

Una vez con la relación en mano, a través de un edicto de visita se hacía comparecer a los albaceas y también a los herederos para que demostraran el cumplimiento de la útima voluntad del difunto, en especial de aquellas cláusulas que afectaban el bien de su alma como misas, aniversarios, capellanías, limosnas, y en general cualquier tipo de obra pía. Esto no era un simple trámite administrativo. Se vivía como grave responsabilidad que recaía sobre albaceas, herederos, clérigos y obispo pues se creía que, en mucho, de su cumplimiento dependía que el alma del difunto, si bien ya salvada, acortara el tiempo de sus sufrimientos en el purgatorio y pasase a gozar de la bienaventuranza eterna ${ }^{31}$.

En obediencia al edicto general de visita del 7 de mayo de 1644 doña Dorotea de Carvajal, en calidad de albacea de su difunto padre, presentábase ante el señor obispo y hacía la siguiente petición y querella contra uno de sus herma$\operatorname{nos}^{32}$. Según su versión de los hechos, su padre Blas Ruiz de Gaona, muerto hacía once años, había dejado en herencia a sus hijos una labor de trigo en el valle de Puruándiro, jurisdicción de Pátzcuaro. Quedaron como albaceas la misma y su hermano Sebastián Ruiz de Carvajal, quienes de concierto con los demás hermanos acordaron que el segundo la tomara en arrendamiento por 150 pesos anuales.

No obstante los numerosos reclamos de Dorotea, según ella decía, el hermano no había pagado la renta desde entonces ni cumplido sus obligaciones de albacea. Por ello, en 9 de septiembre de 1641 el entonces provisor y canónigo Pedro Agúndez de Ledezma había despachado censuras contra Sebastián, para que compareciese ante el vicario de Pátzcuaro Diego Ramírez Grimaldo. Mas el trámite no se cumplió por promoción del sacerdote al beneficio de Irapuato. Ahora, avisado por ella de que daría cuenta de todo al obispo, había huido a Colima. Por último, afirmaba haber cumplido lo más que podía con el testamento, con muchos sacrificios y a pesar de ser «mujer pobre de solemnidad, sola y desvalida.»

El obispo debía resolver un delicado asunto ya conocido previamente por su provisor. Por eso, sin tardanza, manda buscar y traer al hermano de Puruándiro,

31 La naturaleza del purgatorio como una de las creencias más importantes de la catolicidad ha sido estudiada con gran solvencia por Jacques LE GOFF, El nacimiento del purgatorio, Madrid, 1985. Sin embargo, para la historia del Derecho, del Derecho canónico y la justicia resulta de mayor importancia la obra de Harold J. BERMAN, La formación de la tradición jurídica de Occidente, México, 1996, en especial el capítulo IV, «Las fuentes teológicas de la tradición jurídica occidental», pp. 177-211.

32 AHMCR. Negocios diversos, leg. 10 (1644). 
su lugar de residencia y, como no se le encontrara, el 31 de mayo fulmina excomunión en su contra. Al poco tiempo, Sebastían se presenta a declarar. Pintó un panorama de tonos distintos al dibujado por su hermana. Para empezar, aseguraba que era la «mujer sola y pobre de solemnidad» quien se había apoderado de todos los bienes del difunto padre, impidiéndole ejercer su albaceazgo. Además, el arrendamiento de la susodicha tierra lo había hecho sólo por tres años, junto con su cuñado Pedro Ruiz, por la suma total de 150 pesos. Por lo que tocaba al cumplimiento de los mandatos del padre, él tenía pedido junto con su cuñado -ahora viudo y albacea de Gerónima, hermana de Sebastián y Dorotea-, la venta de la labor de trigo para que, con ese dinero no sólo se cumpliera la voluntad de Blas Ruiz, también la de su hermana Gerónima. Terminaba su declaración pidiendo al obispo que, para despejar cualquier duda, la hermana hiciese presentación del testamento del padre y diese relación de todo lo obrado en su calidad de albacea $\mathrm{y}$ tenedor de bienes del difunto.

Poco despues, el 3 de junio, Sebastián la emprende contra su hermana acusándola de vivir amancebada con un tal Miguel de Garselán desde hacía doce años, «dando escándalo y nota en toda la ciudad», quien le impedía rendir cuentas claras del dinero dejado por su padre y cumplir los testamentos de padre e hija en grave perjuicio de sus almas.

Presentado el testamento, Sebastián fue exculpado y se realizó la venta de la labor de tierra de Puruándiro con el fin de cumplir la voluntad de Blas Ruiz y de su hija Gerónima, para que pudieran descansar en paz. Lo que no sabemos es si doña Dorotea pudo finalmente descansar. En todo caso, era claro que el pecado de uno evitaba el descanso de otros y ponía en riesgo el de los demás. Esto era un gran escándalo que el obispo debía prevenir, pues de ello dependía la tranquilidad de muchas conciencias y no menos familias.

Ahora bien, dentro del cumplimiento de los testamentos había un tipo de fundación que en particular preocupaba al obispo. Eran las capellanías que, si bien y por lo regular eran producto de un legado testamentario, también se fundaban por otros medios e incluso en vida misma. Como bien sabemos, estas instituciones resultaban de vincular un conjunto de bienes bajo la responsabilidad de un patrón, quien los pondría a censo para que de sus réditos se pagara un sacerdote capellán que dijese, a perpetuidad por lo regular, cierta cantidad de misas cada año por la salvación del alma del fundador, o bien de otras, más las demás del purgatorio ${ }^{33}$.

33 Las capellanías y diversas fundaciones y corporaciones eclesiásticas han sido bien estudiadas en su dimensión económica y social. Por ejemplo, Ma. del Pilar Martínez LóPEZ-CANO, Gisela VON WOBESER y Juan Guillermo MUÑOZ CORREA (coords.), Cofradías, capellanías y obras pías en 
Las implicaciones de este tipo de fundaciones eran múltiples. Destacamos las siguientes. Primero, eran fuente de ingresos para la iglesia, de empleos para clérigos, de financiamiento para seglares empresarios y modo de vincular la tierra haciéndola inafectable en la medida en que pasaba a ser considerada como bien eclesiástico. Segundo, daban cauce a una de las creencias religiosas del tiempo, de hecho uno de los dogmas de la Iglesia, como era la comunión de los santos, al crear lazos de solidaridad y dependencia entre los miembros de la Iglesia militante, purgante y triunfante. Tercero, incidían directamente -en intensidad y calidad- en el enriquecimiento del culto divino, al fortalecer la espiritualidad de la feligresía. En otras palabras, afectaban toda la vida de la Iglesia entendida como comunidad en su dimensión inmanente y trascendente. Por todo esto, su cumplimiento era de especial preocupación para nuestro obispo en descargo de su conciencia de prelado y pastor y, por supuesto, de la real conciencia. Pero no todos pensaban como el obispo y, en razón de los muchos intereses económicos que suponían las capellanías, había quienes se preocupaban de lo contrario.

De entre los diversos casos que podrían comentarse, en esta ocasión y a modo de ejemplo, quiero llamar la atención sobre lo sucedido en Colima. Por cosas de las que se había enterado, el obispo ordenó una visita especial a los testamentos, capellanías y obras pías. Para tel efecto, nombró al presbítero don Diego Correa Gudiño, juez eclesiástico, vicario in cápite y beneficiado de Caxitlán, como juez eclesiástico y visitador especial; y al beneficiado de Colima, Matheo Ruiz Montaño por defensor de capellanías.

Es importante llamar la atención en el nombramiento de Correa Gudiño para evitar malos entendidos. No se trata de un juez visitador y nada más, sino de un juez visitador que además es un juez eclesiástico delegado. Se trata de una sóla persona ejerciendo dos funciones, dos jurisdiciones coordinadas con un mismo propósito. Ruiz Montaño, a su vez, debía defender a las almas de los difuntos y por eso lo era defensor de las capellanías que les protegían ${ }^{34}$.

la América colonial, México,1998. Rodolfo AgUIRRE, Los fundadores de capellanías y el fortalecimiento del clero secular de México en el siglo XVII, en Roberto GUEDES, Claudia RODRÍGUEZ y Marcelo DE LA ROCHA (coords.), Ultimas vontades: testamento, sociedade e cultura na América Ibérica (séculos XVII e XVIII), Maudad X, Río de Janeiro, 2015, pp. 317-344.

34 Quiero llamar la atención en la tesis doctoral que actualmente se desarrolla en el Posgrado de Historia de la Universidad Nacional Autónoma de México, elaborada por la candidata a doctora Ángeles ESTRADA, la cual lleva por título: Formación, desarrollo y consolidación del juzgado de testamentos, capellanías y obras pías del arzobispado de México, siglos XVII y XVIII. Estamos, con seguridad, ante el primer estudio completo sobre tan importante juzgado. 
En sus averiguaciones, Correa Gudiño no sólo encontró las irregularidades comunes producto de las circunstancias y la debilidad humana. Más grave, no se conocía cuántas capellanías había fundadas y quiénes eran sus responsables. Problema que remontaba sus orígenes hasta 1620 por lo menos. Sus hallazgos pusieron muy nervioso a más de uno. Pensemos en las deudas acumuladas durante todos esos años y la cantidad de tierra inafectable oculta o circulando libremente en el mercado. Más de una conciencia, y no necesariamente conciencia pía, se veía amenazada por el empuje disciplinario del momento.

$\mathrm{Ni}$ tardas ni perezosas «las conciencias», a través del alcalde de Colima Gerónimo de Vitoria, promueven y ganan real cédula para suspender a Correa Gudiño en su cargo de juez eclesiástico. La medida se fundaba en un precedente de Querétaro, donde se había ganado otra similar porque el juez eclesiástico perjudicaba los intereses de los ministros religiosos de una doctrina ${ }^{35}$. Una clásica chicana por medio de la cual «las conciencias» buscaban impedir las averiguaciones. Si bien la suspensión prevenía la intervención de Correa Gudiño, sólo afectaba su competencia en tanto que juez eclesiástico delegado por el obispo; pero en manera alguna involucraba las facultades derivadas de su nombramiento como visitador especial y juez eclesiástico de testamentos, capellanías y obras pías. Las amenazadas conciencias ganando lo menos querían quedarse con lo más.

Era un truco demasiado burdo para la experiencia de Ramírez de Prado. Menos tardo y perezoso inicia contraataque el 22 de enero de 1644. Por un lado, refrenda a Correa Gudiño en su cargo de juez visitador, otorgándole toda su autoridad y jurisdicción. Por otro lado, manda al procurador de la iglesia michoacana en México, canónigo don Juan de Poblete, promover la anulación de la real cédula bajo el argumento de que, en la comarca de Colima existían tres beneficios en los que se administraban indios y españoles, además de que siempre había existido ahí juez eclesiástico por su gran necesidad debido a la lejanía de más de 80 leguas de Valladolid. La promoción de Poblete tuvo éxito y el 11 de julio de 1644 el virrey mandaba recoger la cédula.

Una vez con material suficiente en su haber, el 4 de enero de 1645 Correa Gudiño publica el edicto de visita a través del cual citaba a todos los patrones y capellanes de la comarca de Colima a comparecer, para legitimar sus derechos y responder por sus obligaciones. El trámite debía finiquitarse en tres días y entretanto se les prohibía salir de Colima. Al edicto, agravado con censuras, respon-

35 AHMCR. Negocios diversos, leg. 11 (1645); leg. 12 (1646-49). 
dieron numerosos capellanes y patrones. El mayor de todos, el beneficiado de Colima Matheo Ruiz Montaño «defensor de capellanías».

Entonces, el juez eclesiástico y visitador de capellanías pide a Ruiz Montaño la presentación de todas las escrituras de censo ya pasadas y bajo su responsabilidad. Su respuesta fue simple. No había escritura alguna. Sin ellas no había nada que ajustar ni modo modo de conocer los pendientes; sin pendientes no había nada que poner al corriente y, por ende, ninguna obligación que cumplir de su parte.

Pero el caso del beneficiado de Colima no era excepcional. Del cotejo entre el archivo de Colima y las personas que se presentaron se sacó en claro que había un número considerable cuyas hipotecas estaban ya perdidas, esto es, sin recursos económicos, lo que no excusaba de decir las misas de todas maneras. Las ánimas del purgatorio no tenían la culpa de la mezquindad de las conciencias de la tierra.

Tiempo después, noviembre de 1645, ante la evidencia de las muchas deudas debidas a las capellanías y porque «las misas de tales memorias y capellanías están por decirse en gran daño de las conciencias y [que] las ánimas del purgatorio padecen falta de sufragios», Correa Gudiño manda a Ruiz Montaño que, en su calidad de defensor de capellanías hiciese las diligencias necesarias para el cobro de la dote y la renta de ellas. Según las instrucciones del obispo se debían asegurar, antes que nada, los principales de las capellanías, es decir, los bienes vinculados que las sustentaban, en especial las tierras. ¿Cuántos movimientos de compra venta, traspasos, etc., quedarían en entredicho? ¿Cuántas fortunas quedarían, si no mermadas sí gravadas? ¿Cuántos intereses no se afectarían por esta medida? No hay modo de saberlo. Lo que sí sabemos es que el beneficiado de Colima se negó a cumplir con lo mandado por el juez Correa Gudiño, bajo el pretexto de que en su comisión de defensor de capellanías no se incluía el pago de réditos atrasados, toda vez que eso era asunto de los mismos capellanes.

Topaba todo con el absurdo de negarse el defensor a defender. Así, no había nada que hacer más que recurrir al obispo y eso hizo el visitador especial y juez eclesiástico el 8 de noviembre de 1645. La respuesta de fray Marcos sale de Valladolid hasta el 9 de noviembre de 1647. Justo dos años después. Si bien tarde, autorizaba a Diego Correa Gudiño para nombrar a quien él considerara persona de su entera satisfacción como defensor de capellanías. También remarcaba que éste debería ocuparse del buen cobro de ellas, ajustar cuentas, cobrar réditos y lo demás pertinente para despejar dudas y hacer la distribución de todas las misas pendientes. 
No obstante las muchas dificultades que se tuvieron que enfrentar, al parecer los esfuerzos del obispo encontraron buen cauce a lo largo y ancho del obispado, según el testimonio del canónigo Franco Arnaldo Ysassy quien, ponderando el quehacer del obispo escribía:

Hale gobernado con gran paz y prudencia visitándole y administrando justicia, haciendo cumplir muchos testamentos y legados píos de misas y capellanías que no se habían impuesto ni se decían por la malicia y descuido de los ejecutores y albaceas $^{36}$.

\section{II.3. Del ejemplo de los clérigos}

Tener lugares dignos y decorosos para la celebración del culto divino y tender puentes de solidaridad entre la Iglesia militante y purgante eran condición necesaria para una reforma eclesiástica que quería que los fieles ordenaran sus vidas según la voluntad de Dios; pero no era suficiente. El esfuerzo debía llegar a la vida de los clérigos y de la feligresía.

Dicen que el buen juez por su casa empieza, así que los primeros disciplinados deberían ser los clérigos, beneficiados, vicarios y ministros de doctrina quienes debían «tratar a sus personas, en sus casas, vestido y adorno con la autoridad y decencia que su altísima y nunca bien merecida dignidad pide». Eso significaba acudir a la iglesia correctamente vestidos con sobrepelliz y bonete; escoger sirvientes para sus casas libres de toda sospecha; sentar a su mesa sólo gente muy honesta y conocida de buena vida y costumbres, a menos que fuesen manifiestamente pobres, «cuya compañía es muy decente en la mesa del sacerdote, para lo cual declaramos ser pobre los que no tienen trato, mercancía ni otra cosa de qué sustentarse»; evitar los juegos de naipes ilícitos, y si fueran lícitos ver muy bien con quien se juega, «con conocimiento de lo mucho que se pierde o gana de reputación y ejemplo», en especial ante los indios; y sostener buenas relaciones con las autoridades seculares ${ }^{37}$.

Pues bien, el 6 de abril de 1641 se presentó ante la Audiencia episcopal, en la ciudad de Valladolid, Francisco Rodríguez Torrero vecino de Pátzcuaro y co-

36 Franco Arnaldo YSASSY, Demarcación y descripción de el obispado de Michoacán y fundación de su iglesia catedral (1649), en Biblioteca Americana, vol. 1 (set 1982), p. 108.

37 Colección de las ordenanzas que para el gobierno del obispado de Michoacán..., p. 25. 
merciante importante al parecer. Se querellaba contra el beneficiado de Petatlán, Zacatula, Juan Esteban de Torres ${ }^{38}$.

Hacía tres meses que, al atender en aquel pueblo algunos negocios, había vendido a crédito una mula parda a Simón Delgado, almirante de la China, en 110 pesos. El mismo día se había presentado el beneficiado Juan Esteban de Torres quien, a modo de préstamo al almirante, se había comprometido a pagar la mula. Descontados treinta pesos por un pago que hiciera el beneficiado a nombre del comerciante, la deuda del sacerdote con el comerciante quedaba en los 80 pesos.

Según Rodríguez Torrero, en distintas ocasiones había requerido el pago de la deuda, pero el sacerdote se negaba «con razones feas y descompuestas». El asunto creció hasta llegar al punto de: «con demasiado atrevimiento y descompostura, me ocasionaba apesadumbres desafiándome a campaña diciéndome que no era clérigo y que no reparara en que lo era.» Pero las cosas iban más allá del beneficio de Petatlán y no sólo Rodriguez Torrero tenía problemas.

El presbítero Juan de Castillo se la pasaba viajando de Acapulco a Petatlán. Los productos que traía, ropa y tenería, se los vendía en su curato a todos los vecinos, quienes compraban no necesariamente por su voluntad, para luego vejar constantemente a sus deudores. Y si bien tenía desatendido su beneficio, tampoco se ganaba mucho con su presencia. Según el mismo Rodríguez Torrero, una vez Esteban Rodríguez de Ledezma fue a confesarse con el susodicho cura por haber herido al español Antonio González. Mala hora en la que se confesó, pues el herido resultó ser compadre del confesor quien, a modo de absolución y penitencia, agarró a palos al penitente mientras le decía palabras feas. Como Esteban se quejara ante el alcalde mayor, el sacerdote promovió su excomunión ante el juez eclesiástico de la región, «por haber puesto manos violentas en un sacerdote». Así, no sólo fue excomulgado, también desterrado por tres años de la región por la poderosa mano del alcalde mayor.

Si aquellos curas fueron o no traficantes de lo temporal y lo espiritual, probablemente ya nunca lo sabremos pues, desgraciadamente, no se conservaron los papeles restantes del proceso. Como fuere, algún problema existía en Petatlán y el obispo Ramírez de Prado estaba decidido a salir al paso.

Un año después, 3 de abril de 1642, ante el juez provisor se presentaba Alonso Castellón para querellarse criminalmente contra el vicario de Tiríndaro (provincia de Michoacán) y demás responsables, por haber raptado a su hija Marta un martes 24 de marzo a las 8 de la noche. Según Alonso, «cobijados por el

38 AHMCR. Negocios diversos, leg. 8 (1640-41). 
manto de la obscuridad» se presentaron en la estancia de Cotijo, donde tenían su morada, los indios Juan y Gerónimo y, «sin ser fiscales eclesiásticos», se llevaron a su hija doncella a casa del vicario, quien la tuvo durmiendo en su aposento «una noche y un día con notable escándalo de los naturales».

Afirmaba que, ante sus amenazas de dar cuenta de todo al obispo, el vicario había accedido a ponerla en depósito en el hospital del lugar. Agregaba Alonso que el susodicho presbítero había escudado su reprobable acción en que su hija se quería casar con un indio vecino de Tiríndaro. Trato inaceptable para el padre pues, afirmaba, ella ya estaba comprometida con un español de Cocupao (hoy Quiroga) llamado Juan de Arteaga. Por todo lo anterior, pedía fuese traída su hija a la ciudad de Valladolid y el vicario severamente castigado ${ }^{39}$.

Desgraciadamente, tampoco conoceremos el desenlace de esta historia. Sin embargo, es probable que se tratase no tanto de un cura desencaminado, sino de un indignado padre que, contra los deseos de su hija, prefiriese un matrimonio para él más decoroso. En tal caso, el vicario habría procedido legítimamente a garantizar la libertad matrimonial de la doncella, como era su deber ${ }^{40}$. Lo que llama la atención es que, según la experiencia de archivo, el provisor siempre daba entrada a las denuncias contra cualquier clérigo.

Como podemos apreciar, estos procesos tenían un mar de fondo, no siempre explorable, donde se encontraban calumnias, intereses creados, dobleces y relaciones verídicas. Como fuere, la mejor solución era prevenir antes que lamentar. Por ello, el mejor recurso era mantener la visita permanente, sin no de todo el obispado, seguro por todo el obispado. De esto nos llega noticia desde Pintzándaro (Tierra Caliente), a través del visitador don Diego Ramírez Grimaldo beneficiado de Irapuato y caballero de la orden de San Juan. El 25 de mayo de 1646, entre las muchas actividades del visitador, estuvo la de levantar información entre los fieles de Pintzándaro sobre la «vida y costumbres» del cura Cristóbal de Peñaloza quien, de tiempo atrás, había sido acusado de diversas irregularidades por miembros de su feligresía.

39 AHMCR. Negocios diversos, leg. 9 (1642-43).

40 La libertad matrimonial es uno de los elementos claves para entender la naturaleza de esta institución en aquellos tiempos. Siempre será imprescindible la ya clásica obra de Patricia SEED, Amar, honrar y obedecer en el México Colonial. Conflictos en torno a la elección matrimonial, 1574-1821, México, 1991. Asimismo, la obra de Dora DÁvILA MENDOZA, Hasta que la muerte nos separe: el divorcio eclesiástico en el arzobispado de México, 1702-1800, México, 2005. En lo personal he estudiado el problema en Jorge TRASLOSHEROS, Iglesia, justicia y sociedad en el arzobispado de México, capitulo quinto, «La audiencia arzobispal y la vida matrimonial», pp. 134-160. 
Fueron llamados a declarar y declararon Felipe Juan, indio principal de 60 años de edad. Francisco Pérez, indio y alcalde de edad de 40 años. Francisco Luis, indio y alcalde de 35 años de edad. El presbítero Pedro Baca Coronel de 38 años. Don Manuel Franco de Mendoza, español de 37 años. Y don Juan Baca Coronel, español y escribano público de 36 años. Todos, coincidieron en señalar a su párroco como hombre «honesto, temeroso de Dios y su conciencia», quien acudía a administrar los santos sacramentos con gran «caridad y celo», sin dejar a nadie morir sin confesión y santos óleos por descuido u omisión de su parte, además de predicar y confesar a los naturales en su propia lengua. Si por alguna razón iba a fiestas del pueblo, dejaba ministro de doctrina en su lugar y, en caso de no poder asistir, mandaba sustituto aprobado por el obispo. Tampoco tenía tratos ni contratos de mercancía por sí ni por otra persona. Siempre había pagado a quien le trabajara sus sementeras. No había vendido ni empeñado los ornamentos de la iglesia, antes bien los había aumentado. Decía misa en los barrios del pueblo, enseñaba la doctrina a niños y niñas en persona o bien a través de sus ministros indios. Tampoco trataba con mujer, ni había molestado a nadie o tratado familiarmente con alguien. Y, por supuesto, no había promovido escándalos ${ }^{41}$.

Si el beneficiado de Pinztándaro había sido alguna vez hombre divertido y escandaloso, ahora se había transformado en un modelo así de doctrinero como de párroco, ajustado ejemplarmente a la disciplina impuesta por el Concilio de Trento, los breves pontificios y las Ordenanzas Generales de fray Marcos Ramírez de Prado, a su vez deseadas por Su Majestad. La presencia del visistador nombrado por el obispo había probado que se trataba de un sacerdote cuya vida servía de «ejemplo y edificación» a su feligresía.

\section{II.4. De las costumbres de los fieles}

Ajustar la disciplina de los clérigos era asunto difícil; pero no lo era menos el ciudar las costumbres de los fieles, indios y no indios. El pecador público y escandaloso, ese delincuente vulgar, podía aparecer en cualquier lugar, fuese clérigo o simple seglar.

Había que estar alerta contra excomulgados, herejes, apóstatas, juradores, hechiceros, curanderos, usureros, violadores de templos y cementerios, amance-

41 AHMCR. Negocios diversos, leg. 12 (1646-49). 
bados, casados separados, bígamos, quienes hablaran mal de la jerarquía eclesiástica, así como cuidar que se cumpliera con los preceptos de comulgar y confesar. Esto como lo principal. Resultaba difícil llenar tan pecaminosa lista por parte de los fieles y, desde luego, no es pensable una total relajación de las costumbres aunque no faltó, como no podía faltar, quien viera en algún pueblo o villa la reinvención de Sodoma y Gomorra.

De tal imaginación fue don Juan de Sepúlveda, teniente de alcalde mayor del beneficio de Los Pozos, quien presentó ante fray Marcos, de visita en el lugar, tremenda denuncia del siguiente tenor ${ }^{42}$ :

Por asegurar mi conciencia y para que vuestra ilustrísima descargue la suya, sin ánimo de denunciar a nadie pues no puedo teniendo el oficio que tengo y debiendo remediar yo algunas de las cosas que diré [...] y porque es todo tan público y escandaloso.

Presentaba la siguiente lista de delitos: Juan Sánchez Vadillo, quien estaba casado en Celaya, tenía muchos años sin vida maridable, al igual que Gaspar de Masqua vecino de Jacona. Además, ambos estaban amancebados. Y si de amancebados se trataba, pues ahí estaban Alonso García con una mujer casada; Juan López con una mulata que tenía dentro de su casa llamada Agustina; Domingo de Caudo con una mestiza llamada Beatriz; Alonso de Flores con una moza hija de un vecino, «y tiene reputación de doncella»; Pedro Puga con una mujer «que se descasó por pleito y tiene un tablaje público en su casa»; el Lic. Antonio Pérez, mercader de plata, tenía criada amancebada y «trato asentado» con todos los mercaderes de Los Pozos; el indio carpintero Lázaro lo estaba con una india llamada Magdalena quien tenía su esposo ausente, y todos los vecinos tenían sirvientes indios amancebados en sus casas, que es cosa que ocultan.

También los clérigos tenían cosas para dar cuenta, como don Juan de Moreira, beneficiado de Tlazazalca, quien trataba con la viuda Philipa; y el Lic. Pedro Muñoz con otra viuda de nombre Isabel, sin contar con que todos los clérigos jugaban públicamente con mujeres. $\mathrm{Y}$ entre esos clérigos estaba por supuesto el beneficiado, a quien constaban todos estos pecados y de los cuales no daba cuenta porque, «es público que está amancebado con una mujer que tiene en su casa que llaman la China», además de ser descuidado en sus obligaciones y residir en San Luis Potosí. Y para terminar, observaba que los mismos fieles eran incumplidos en sus deberes religiosos pues no acudían a misa ni se guardaban de trabajar en

\footnotetext{
42 Ibidem.
} 
días de fiesta. Firmaba don Juan de Sepúlveda, teniente de Los Pozos, «sin ánimo de denunciar a nadie».

Es poco probable que Los Pozos fuera le revivificación de Sodoma y Gomorra, aunque hubiese quien lo facilitara por medios que, para aquel entonces, eran considerados de dudosa procedencia. Tal fue el caso de una hechicera mulata del beneficio de Santa Clara la cual, haciendo causa con las mujeres maltratadas por sus maridos por los celos y las borracheras, preparaba un brebaje de cucarachas de tierra caliente de color negro, para que: «los hombres casados aunque vean algunas cosas contra su honra no se den por entendidos... aunque la viese [a su esposa] hablar [o] estar con hombres.» Razón por la cual el Provisor mandó realizar averiguaciones para ver si procedía denunciarla ante la Inquisición ${ }^{43}$.

No obstante, la principal preocupación eran las relaciones entre hombres y mujeres, en especial bajo tres situaciones: los que tenían cónyuge, pero no lo querían; los que teniendo, querían más; y los que, si bien le tenían, no era como debían. Casados separados, bígamos y amancebados.

A quienes no vivían con su legítima esposa por lo regular se les obligaba, bajo pena de excomunión, a acudir a sus obligaciones en el más amplio sentido de la palabra. Aunque no siempre era posible, como fue el caso de Agustín Barbosa ${ }^{44}$. El 18 de marzo de 1645, el «vicario in cápite y juez eclesiástico de Colima», don Diego Correa Gudiño, mandaba a Agustín Barbosa que, en plazo de treinta días acudiese a vivir con su mujer legítima, lo que no hacía de muchos años atrás, so pena de excomunión mayor y una multa de 100 pesos de oro.

En julio del mismo año, Barbosa se presentaba ante el juez. Le era imposible cumplir con el mandamiento pues hacía siete años que su mujer, «engañada del demonio», se le había ausentado. Según los testigos, Agustín Barbosa y Ana de Ayala, legítimamente casados, vivieron en Pátzcuaro en una casa decente y procrearon dos hijos. Sólo que, sin poderse determinar la causa, estando él en viaje de negocios y no obstante haberle dejado crédito abierto en tres tiendas para su sustento, ella abandonó el hogar y a sus hijos.

El abandonado le había buscado en Tlalpujahua, Caltepeque, Taxco y muchos otros lugares de la Nueva España sin éxito alguno, de modo que era imposible saber si estaba escondida o bien, muerta. Terminadas las averiguaciones. Agustín fue condenado, bajo juramento, a proseguir permanentemente su bús-

43 AHMCR. Averiguación encomendada por el Vicario y Provisor del obispado Lic. Don Pedro Agúndez de Ledezma, al beneficiado de Santa Clara para determinar si la causa debe ser mandada al Santo Oficio de la Inquisición. Negocios diversos, leg. 9 (1642-43).

44 AHMCR. Negocios diversos, leg. 11 (1645). 
queda: «agora y en cualquier tiempo que supiere o tuviere noticia en qué parte o lugar asista o esté Ana de Ayala su legítima, irá a vivir y cohabitar con la susodicha según y como es obligado por derecho divino y humano».

Si había quienes aun queriendo no podían vivir con sus mujeres, hubo otros que no se bastaron con una, como el indio Angel Porecu, vecino de Santa Ana Amatlán quien se casó dos veces, la segunda con una vecina de Santa Clara y bajo el nombre de Pedro Porecu. Un escándalo que era, a su vez, un crimen de bigamia. Fue condenado por el juez comisionado y beneficiado de Pintzándaro Cristóbal de Peñaloza a:

En día festivo al tiempo de la misa mayor, sea sacado [de prisión] con una corsa de papel en la cabeza y en ella dos mujeres pintadas y con una soga en la garganta, las manos atadas y desnudo de la cintura para arriba, y alrededor de la iglesia parroquial de dicho pueblo de Pintzándaro le sean dados cien azotes con trompeta y voz de pregonero que en la lengua de dichos naturales (...) publique su delito con castigo del susodicho y ejemplar de los demás naturales llevándolo en forma de justicia ${ }^{45}$.

Finalmente estaban los que, si bien «ayuntados», no lo hacían conforme al derecho divino y humano. Eran los amancebados quienes eran causa de mayores escándalos. Por ejemplo, en diciembre de 1645, don Joseph López de Hinojosa juez visitador por fray Marcos Ramírez de Prado, de paso por Tzitácuaro, procedió judicialmente contra Luis Torres, español, por sostener trato ilícito con Juana de Mercado, mestiza. Habían vivido amancebados por más de un año «con grande nota y escándalo», lo que era «público y notorio, pública voz y fama». Hechas las averiguaciones y confesado su culpa se condenó a Luis Torres dejar a Juana de Mercado. Si reincidía sería desterrado dos años del lugar, por lo menos. La condena, al final, no pasó de una simple amonestación para vivir en orden, muy probablemente porque se trataba apenas de dos muchachos ${ }^{46}$.

Por mi experiencia de archivo puedo decir que, por lo regular, la suerte de Luis Torres era compartida en estos casos. Sin embargo, las cosas no siempre eran tan claras, toda vez que golpear el honor de un sujeto otorgaba ventajas sobre el enemigo, políticas y económicas regularmente. No era necesario que culminara el proce-

45 AHMCR. Negocios diversos, leg. 9 (1642-43). Pintzándaro, 5 de noviembre de 1642. Este caso reviste especial importancia pues demuestra, una vez más, que la jurisdicción sobre los delitos cometidos por los indios contra la fe permaneció en manos de los obispos. Cfr. Gerardo LARA CISNEROS, ¿Ignorancia invencible? Superstición e idolatría ante el Provisorato de Indios y Chinos del Arzobispado de México en el siglo XVIII, México, 2014. Jorge TRASLOSHEROS, Iglesia, justicia y sociedad..., pp. 107134.

46 AHMCR. Negocios diversos, leg. 11 (1645). 
so, pues bastaba con promoverlo y mientras más oscuro quedara todo, tanto mejor contra la reputación del inculpado. Por lo mismo, los jueces eclesiásticos debían procurar disipar cualquier duda. La lucha contra los pecados públicos y escandalosos topaba con innumerables problemas derivados de la fragilidad humana, tan común como el pecado, tan cotidiana como la vida misma. No obstante, existía un enemigo de mayor calado. Tal era el falsario, el calumniador, en los hechos el gran escandalizador. Ente muchos casos que podríamos citar, el más ilustrativo es el siguiente.

El 10 de octubre de 1645, el provisor y vicario del obispado de Michoacán firmaba un auto por el cual daba al beneficiado de Tlazazalca, don Juan de Moreira -exvicario de Los Pozos y ex visitador de Zacatula-, comisión de juez especial para levantar ciertas averiguaciones ${ }^{47}$. Debía proceder con absoluta discreción para evitar que nadie, a no ser él mismo, se enterase de un muy serio problema, según denuncia presentada ante el tribunal eclesiástico contenida en dos cartas anónimas, una dirigida al obispo y otra al provisor. De escritura maltrecha y tormentosa redacción, en ellas se podía leer:

Fray Marcos Ramírez de Prado, obispo de esta provincia de Michoacán, humildemente hago saber a su ilustrísima como [en la] jurisdicción de Tlazazalca, [en] la estancia que llaman de Tzináporo, ahí vide a un hombre que está haciendo [in]cesto con una mujer casada, llamado su marido Pedro de la Serna, español y [la] mujer Inés de Coca. [El hombre se llama] Amado Cristóbal López, mulato de mucha razón con poco miedo de Dios ni la justicia [y] porque todos son parientes en aquella estancia lo tienen ocultado porque están cohechando y dan mal ejemplo. [Cristóbal] primero estaba amancebado con la [hermana] mayor llamada Juana de Coca, y se revolvió con [la] menor que llaman Inés de Coca. [Inés de Coca a su vez] primero trataba con un hermano [de Cristóbal] llamado Pedro López [...] Después que supo [Cristóbal] que su hermano [la] trataba, fue al momento largo y están juntos [Inés, Pedro de la Serna, Cristóbal y Pedro López] en una casa. Y sabe claramente su marido y conociendo a su mujer que claramente tiene la mitad [de hijos] de mulatos y la mitad hijos de su marido [que] siendo español da mal ejemplo. Y más tiene a su hija del dicho Pedro de la Serna reputación de doncella y está pariendo de un Indio. [Pedro de la Serna] su padre propio lleva a dar [los niños] a los puercos para que coman y para que no sepan sus vecinos. Y yo he confesado la cuaresma con un fraile y no me quería absolverme. Lo cual conté todo como está y me dijo del dicho confesor que los acusara [...] que si no estaba yo descomulgado sabiendo yo que hacían mal cristiandad y que sean sus almas libres conforme de lo que se puede hacer, que no se haga mal ejemplo y ésta es la verdad declaración, no más. Cinco de octubre de 1645 años. No más.

47 Ibidem. 
Don Juan de Moreira inicia interrogatorios el 2 de enero de 1646. El primero en declarar fue don Francisco Magaña, mestizo, vecino de Tzináporo de edad de 30 años, esposo de la sobrina de Cristóbal López. Según sus palabras, había oído decir a una india llamada Beatriz, esposa del indio Agustín, que en efecto existía amancebamiento entre Inés y Cristóbal. Y no sólo lo decía Beatriz, que eso era «voz pública» según los mismos habitantes de aquella estancia.

El segundo en declarar fue Diego de Madrigal, teniente de corregidor en Penjamillo, jurisdicción de Tlazazalca, de 45 años. Dijo que, enterado del asunto y habiendo hecho averiguaciones por su cuenta, supo que el autor de las cartas era un tal Juan de Cáceres, mestizo, a quien él mismo había reprendido, «porque había escrito semejantes cartas en deshonor de otras personas». A lo que Cáceres respondió haberlo hecho por venganza, pues aquellos habían declarado en su contra ante el alcalde de la Hermandad. Finalizaba su testimonio pidiendo no se procesara a los inculpados.

Dos versiones distintas. La palabra de un teniente de corregidor, contra otra soportada en las voces «públicas y notorias» de la estancia de Tzináporo. Y a esas voces se procedió a interrogar. El 4 de febrero a Bernardina López y el 20 del mismo mes a María López, Catalina López, Beatriz López y Bernardina de Artiga.

Bernardina López, india ladina y criada de Pedro de la Serna, poniendo la mano sobre el pecho y jurando por Dios y la Cruz decir verdad -como hacían todos los testigos-, dijo que oyó decir que en aquella estancia se decía lo mismo que en las cartas. Ella por su parte, criada celosa «y por ver si era cierto», esperó y vigiló «días y noches», pero nunca vio nada, «ni que los viese jamás en parte sospechosa». Ni siquiera escuchó «palabras descompuestas». Remataba su declaración añadiendo que ella, «como nacida y criada en dicha casa no podía dejar de ver cosas de las contenidas en dichas cartas, con que echó de ver que era embuste y testimonio que había levantado porque lo tiene de maña y por vicio la india Beatriz».

Las declarantes del 20 de febrero confirmaron esta versión. De cierto no sabían nada de lo contenido en las cartas, tan sólo se lo habían oído decir a la tal Beatriz, «y como era india de mala lengua y descompuesta no la creyeron.» Pero eso sí, como sabían que era mentirosa, ellas hicieron «muchas diligencias secretas» por saber si era verdad, $\mathrm{y}$ «hallaron ser falso». Agregaban, para terminar, que era venganza contra sus patrones, pues le «reprendían su maldad y le obligaban a que hiciera vida con su marido.» De entre tantas diligencias secretas realizadas por los testigos, más las propias de don Juan de Moreira, poco a poco salía una versión consistente y no tan secreta. 
Para completar el cuadro apareció Domingo Moreno, vecino de Penjamillo, quien resultó ser un voluntario y voluntarioso detective. Entregó sus pesquizas al juez eclesiástico un 12 de diciembre de 1646, sin pedir nada a cambio. Según Moreno, en conocimiento de la existencia de esas dos cartas hizo «diligencias secretas», sin poder averiguar nada malo de Cristóbal López; pero sí de una «mala mujer» llamada Beatriz. Sin embargo, encontró algo más importante.

Hacía como diez meses se había encontrado con Juan de Cáceres quien iba con su recua rumbo a Zacatecas. Inquirido por el testigo, Cáceres le contestó, «que [se] quería ir de la Jurisdicción y que no había de vivir en ella que todos le querían mal». Moreno le respondió que eso era natural pues se había dedicado a «deshonrar mujeres casadas y doncellas imputando delitos falsos.» Cáceres, según versión del esforzado detective, había tratado de defenderse con el argumento de que él no había escrito esas cartas, sino un bachiller de Pátzcuaro quien puso lo que quiso «que yo no se lo dije así». Pero la evidencia estaba en su contra pues, «el mismo lenguaje que él habla traen las cartas.»

Guiado por sus discretos y sigilosos testigos, el juez comisionado Juan de Moreira se topaba de frente con Juan de Cáceres como presunto culpable de tantas calumnias. Llamado a declarar, el acusado negó los cargos y culpó al supuesto bachiller de Pátzcuaro de la versión escrita y, para probarlo, pedía los testimonios de algunos vecinos de Tzináporo, en especial de las mujeres. Obvio, no sabía que ya habían declarado, lo que no privaba de que volvierona a declarar. Sin embargo, ya no se pudo llevar adelante la diligencia pues Juan de Cáceres, en la primera oportunidad, se esfumó.

Don Juan de Moreira dio por terminadas las averiguaciones y remitió todos los autos al juez provisor el 31 de diciembre de 1646. Catorce días después recibió por respuesta el mandato de «prender el cuerpo» de Juan de Cáceres, con ayuda del brazo secular, único facultado para llevarlo a cabo.

Los esfuerzos de don Juan de Moreira fueron inútiles. Lugar a donde llegaba se enteraba que la misma gente, sabedora del sucio proceder de Cáceres, lo expulsaba del sitio. Y así hasta los linderos de Tlazazalca sin poder «prender su cuerpo». Por fin, un 24 de julio de 1647, el juez eclesiástico delegado se tuvo que conformar con embargar cinco cargas de loza de Tzintzuntzan que el repudiado había abandonado en su fuga.

La justicia eclesiástica, auxiliada por la secular, no había podido atrapar al autor del escandaloso infundio. Sin embargo, la justicia se había hecho sin tribunales ni jueces. La «vOz pública», identificada con la causa y los valores que la orientaban había desterrando al falsario. 
Según parece, aquella sociedad podía tolerar -incluso consentir- al pecador discreto y colaborar con los jueces eclesiásticos contra el pecador público. Pero llegado el caso, procedería implacable contra el gran escandalizador, contra el calumniador, contra esos sediciosos que atentaban contra la armonía y la paz sociales.

A pesar de las dificultades, el obispo fray Marcos Ramírez de Prado, sus visitadores y sus jueces, daban batalla para implantar una disciplina capaz de orientar por caminos de virtud la vida y costumbres de los fieles. Podía contar con una sociedad que, de alguna manera, tomaría el asunto como propio y, sobre esta base y límites, fincar el éxito de la reforma de la Iglesia de Michoacán.

\section{REFLEXIONES FINALES}

En el presente texto hemos observado el desarrollo de una reforma eclesiástica a ras de suelo, según lo sucedido en el obispado de Michoacán bajo la gestión del obispo fray Marcos Ramírez de Prado. Así, hemos podido apreciar cómo el Derecho canónico, la visita episcopal y la Audiencia eclesiástica, con su red de jueces comisionados y delegados, operan de manera conjunta cual eficaces medios de reforma en manos de nuestro obispo. Un hábil orfebre que utiliza con maestría sus instrumentos.

Los esfuerzos de Ramírez de Prado se centran en ordenar cuatro aspectos: las relaciones de las personas con Dios dentro de un espacio apropiado a su intención; las relaciones entre los miembros de la Iglesia militante y la purgante, es decir, de los vivos con las ánimas del purgatorio; la reconstitución de las relaciones interpersonales del clero con la feligresía y; la reconstitución de las relaciones de la feligresía entre sí. Siempre, en batalla contra el pecador público y escandaloso.

En esta dinámica de relaciones interpersonales el plano inmanente-histórico se encuentra en estrecha relación con el plano trascendente-salvífico. Reformar, entonces, implica tres movimientos dentro de solo proceso: otorgar su justo orden a las relaciones personales; para fomentar dinámicas de relaciones humanas que pusieran a las personas en la posibilidad de decidir y elegir lo correcto; a fin de alcanzar la vida eterna. Así, la reforma podría provocar la formación de una comunidad que, dado el carácter confesional de la Monarquía, es política, social y eclesial en diversos niveles: personal, familiar, coroportiva, parroquial, diocesana, episcopal y monárquica, siempre dentro de la Iglesia universal. Podemos afirmar, entonces, que no estamos ante un proyecto de reforma de carácter individualista, de moral intimista y puritana, en donde cualquier esfuerzo humano revierte a la 
exlusiva relación entre un Dios omnipotente y un sujeto sin posibilidades ante los implacables designios del Creador.

Acorde a la evidencia con que contamos, podemos decir que estamos ante una Iglesia que parece orientar la reforma sobre la base de un realismo antropológico casi lapidario. Los problemas entre los seres humanos, así como para reconstituir las relaciones interpersonales se dan por descontados. La fragilidad humana es un dato que hace necesarios los mecanismos de prevención y corrección jurídicos y judiciales. Aquellas personas quieren tener una buena vida para alcanzar, según sus propias creencias, la mejor de las vidas; pero también saben que nadie puede lograrlo por su propio esfuerzo. Requieren de una sana relación consigo mismos, con Dios, con los santos y el prójimo, con el apoyo y bajo la mirada constante de la Iglesia y de Su Majestad. Se quiere reformar para ordenar; ordenar para salavar a la sociedad y la monarquía en la historia, como a cada persona en el más allá.

No debe sorprendernos, entonces, encontrar una socieda que puede tolerar e incluso convivir con el pecador ordinario en la medida en que todos saben que son pecadores; pero que tomará medidas contra el escandalizador, de manera notable contra el falsario, el gran calumniador, porque es un criminal que rompe con el tejido social. La convergencia de intención entre el obispo, el clero y la feligresía se comprende.

Para poner las cosas en perspectiva, cabe llamar a la memoria dos decretos del Concilio de Trento: sobre el purgatorio y sobre la justificación. El primero nos recuerda los lazos de solidaridad e interdependencia que existen entre quienes ya se han salvado, pero aún deben purificar sus almas, con cuantos se encuentran en este mundo batallando por su salvación, así como la pertinencia de los medios religiosos que refuerzan esas relaciones, sean sacramentales, litúrgicos, doctrinales, devocionales y las distintas formas de organización eclesial. El segundo, nos ubica en la dinámica de la salvación en su relación con la libertad y la gracia. Si bien es cierto que la salvación eterna es un asunto que la gracia de Dios hace posible, también lo es que requiere de la voluntad de cada persona para ganarla a través de las obras de caridad y misericordia, abierta a la gracia que se derrama en la oración, el culto, los sacramentos y cuantos medios quiera utilizar $\operatorname{Dios}^{48}$. Ambos decretos consideran que las relaciones interpersonales con Dios, el prójimo y los miembros de la Iglesia purgante y triunfante son necesarios a

48 En este sentido, me parece que una de las obras del tiempo que mejor nos puede ayudar a comprender la relación entre la libertad y la gracia es, El condenado por desconfiado, del gran Tirso de Molina. 
la salvación, lo que impacta decisivamente las formas de organización política, social y eclesial. Tengo para mí que nos hace falta estudiar con mucho mayor detenimiento el dogma de fe que está en cada uno de estos esfuerzos y que, en mi opinión, es clave para entender aquel mundo religioso y mucho del sentido de la reforma católica. Me refiero, claro está, a la comunión de los santos que de inmediato nos refiere a los lazos de unidad, solidaridad e interdependencia que existen entre los miembros de la Iglesia militante, purgante y triunfante quienes, en su cunjunto, forman una única y gran Iglesia encabezada por Cristo.

En razón de todo lo anterior, resulta comprensible el realismo con el cual procede nuestro obispo. Crea Derecho canónico diocesano vinculado a la gran tradición eclesiástica; pero lo hace a partir de la directa observación de las necesidades de la feligresía, entendidas en sentido inmanente y trascendente. De igual forma, la visita episcopal y la Audiencia eclesiástica se adecuan a estas realidades como medios de prevención y corrección de conductas no deseadas. La dimensión normativa y de justicia es coadyuvantes del gran objetivo pastoral que desborda con mucho lo estrictamente jurídico y judicial. En otras palabras, el Derecho canónico, la visita episcopal y la Adiencia eclesiástica fueron servidores eruditos, poderosos y eficaces al servicio de la reforma católica en la temprana modernidad. Como nos ha quedado claro, instrumentos de gran calidad y eficacia en manos de este hábil orfebre que fue el obispo de Michoacán, fray Marcos Ramírez de Prado.

\section{REFERENCIAS BIBLIOGRÁFICAS}

\section{Archivos}

ARCHIVO HISTÓRICO MANUEL CASTAÑEDA RAMÍREZ, CASA DE MORELOS. Ciudad de Morelia, Michoacán, México. Ramo Negocios Diversos.

\section{Bibliografía}

AGUIRRE, Rodolfo, Los fundadores de capellanías y el fortalecimiento del clero secular de México en el siglo XVII, en Roberto GUEDES, Claudia RODRÍGUEZ y Marcelo DE LA ROCHA (coords.), Ultimas vontades: testamento, sociedade e cultura na América Ibérica (séculos XVII e XVIII), Maudad X, Río de Janeiro, 2015.

Alvarez De Toledo, Cayetana, Politics and Reform in Spain and Viceregal Mexico: The Life and Thought of Juan de Palafox, 1600-1659, Oxford University Press, New York, 2004. 
Berman, HAROLD J., La formación de la tradición jurídica de Occidente, Fondo de Cultura Económica, México, 1996.

CASILlaS Y CABRERA, Francisco, Colección de las ordenanzas que para el gobierno de el obispado de Michoacán bicieron y promulgaron con real aprobación sus ilustrísimos señores prelados, de buena memoria, D. fr. Marcos Ramírez de Prado y D. Juan de Ortega y Montañez, por don Felipe de Zúñiga y Ontiveros, México, 1776.

CAVAllaRIO, Domingo Instituciones del Derecho canónico, imprenta de Don José María Repullé, Madrid, 1838.

DÁvIla MENDOZA, Dora, Hasta que la muerte nos separe: el divorcio eclesiástico en el arzobispado de México, 1702-1800, El Colegio de México, Universidad Andrés Bello, México, 2005.

ESTRADA, Ángeles, Formación, desarrollo y consolidación del juzgado de testamentos, capellanías y obras pías del arzobispado de México, siglos XVII y XVIII, UNAM, México, tesis doctoral en desarrollo.

Guedes, RoberTO, Claudia RoDRÍGUEZ y Marcelo DE LA RoCHA (coords.), Ultimas vontades: testamento, sociedade e cultura na América Ibérica (séculos XVII e XVIII), Maudad X, Río de Janeiro, 2015.

GonZález DávILA, Gil, Teatro eclesiástico de la primitiva iglesia de las Indias Occidentales, por Diego Díaz de la Carrera, Madrid, 1649.

Headley, John M. y John B. Tomaro (eds.), San Carlo Borromeo. Catholic Reform and Ecclesiastical Politics in the Second Half of the Sixteenth Century, The Folger Shakespiare Library, Associated University Press, Washington-London-Toronto, 1988.

ISRAEL, Jonathan I, Razas, clases sociales y vida politica en el México Colonial. 1610-1670 Fondo de Cultura Económica, México, 1980.

LARA CISNEROS, Gerardo, ¿Ignorancia invencible? Superstición e idolatría ante el Provisorato de Indios y Chinos del Arzobispado de México en el siglo XVIII, México, Universidad Nacional Autónoma de México, 2014.

LE GOFF, Jacques, El nacimiento del purgatorio, Taurus, Madrid, 1985.

Martínez LóPeZ-CANo, Ma. del Pilar; vON Wobeser, Gisela y Guillermo, Juan, Cofradías, capellanías y obras pías en la América colonial, UNAM, Instituto de Investigaciones Históricas, México, 1998.

MuÑoz CORREA (coords.), Cofradías, capellanías y obras pías en la América colonial, UNAM, Instituto de Investigaciones Históricas, México, 1998.

Murillo Velarde, Pedro, Curso de Derecho canónico e indiano, El Colegio de Michoacán, Facultad de Derecho, Universidad Nacional Autónoma de México, Zamora, 2004

O’Malley, John W., Trento. ¿Qué pasó en el concilio?, Sal Terrae, Maliaño (Cantabria), 2015.

Palau y Dulcet, Antonio, Manual del librero hispanoamericano, Ollero, Madrid, 1990.

PÉREZ PUENTE, Leticia, Los cimientos de la Iglesia en la América española. Los seminarios conciliares, siglo ХVI (La Real Universidad de México. Estudios y textos, 36), IISUE-UNAM, México, 2017.

PoOLE, Stafford, Pedro Moya de Contreras: reforma católica y poder real en Nueva España, El Colegio de Michoacán, Zamora, México, 2012.

Recopilación de las leyes de los reinos de las Indias, Porrúa, Escuela Libre de Derecho, México, 1987.

Sacrosanto y ecuménico Concilio de Trento, París, edición latino/español de la librería Garnier hermanos, México, 1885. 
SEED, Patricia, Amar, honrar y obedecer en el México Colonial: conflictos en torno a la elección matrimonial, 1574-1821, Consejo Nacional para la Cultura y las Artes, Alianza, México, 1991. SolórZano y Pereyra, Juan de, Política Indiana, Atlas, Madrid, 1972.

Tercer Concilio Provincial Mexicano, México, edición de Eugenio Maillefert y compañía, 1859. Publicado por Mario Galván Rivera y anotado por el R. P. Basilio Arrillaga, S. J.

Toribio Medina, José, La imprenta en México. (1534-1821), UnAM, México, 1989.

Traslosheros, Jorge, La reforma de la Iglesia del Antiguo Michoacán, Universidad Michoacana de san Nicolás de Hidalgo, Morelia, 1995.

- Iglesia, justicia y sociedad en la Nueva España. La Audiencia del Arzobispado de México, 15281668, Porrúa, Universidad Iberoamericana Santa Fe, México, 2004.

- Historia judicial eclesiástica de la Nueva España. Materia, método y razones, Porrúa, Instituto de Investigaciones Históricas, UNAM, México, 2014.

YSASSY, Franco Arnaldo, Demarcación y descripción de el obispado de Michoacán y fundación de su iglesia catedral (1649), en Biblioteca Americana, vol. 1, n. ${ }^{\circ} 1$ (septiembre, 1982). 
